\title{
Lithium Chloride Enhances Cathepsin H Expression and BMP-4 Degradation in C3H10T1/2 Cells
}

\author{
Koshi N. Kishimoto and Eiji Itoi \\ Department of Orthopaedic Surgery, Tohoku University School of Medicine, 1-1 Seiryo-machi, Aoba-ku, Sendai 980-8574, Japan \\ Correspondence should be addressed to Koshi N. Kishimoto; kishimoto@med.tohoku.ac.jp
}

Received 10 July 2013; Accepted 26 September 2013

Academic Editor: Sue-Hwa Lin

Copyright ( $) 2013$ K. N. Kishimoto and E. Itoi. This is an open access article distributed under the Creative Commons Attribution License, which permits unrestricted use, distribution, and reproduction in any medium, provided the original work is properly cited.

The effect of canonical Wnt/ $\beta$-catenin signaling on chondrogenic differentiation induced by transfection of BMP 4 expressing plasmid was analyzed. Lithium chloride $(\mathrm{LiCl})$ which mimics canonical $\mathrm{Wnt} / \beta$-catenin signaling was added to cells transfected with BMP4 expressing plasmid. Although BMP4 mRNA expression was not affected by $\mathrm{LiCl}, \mathrm{LiCl}$ decreased BMP4 protein accumulation. Gene expression analysis exhibited upregulation of cathepsin $\mathrm{H}$ by $\mathrm{LiCl}$ treatment. Gene silencing of cathepsin $\mathrm{H}$ enhanced BMP4 protein accumulation from BMP4 expressing cells. These results suggested that cathepsin $\mathrm{H}$ is regulated by $\mathrm{Wnt} / \beta$-catenin signaling and plays an important role in the regulation of BMP4 biological activity.

\section{Introduction}

Bone morphogenetic proteins (BMPs) play critical roles in chondrogenic and osteogenic differentiation of mesenchymal multipotent cells [1]. The use of BMPs is a promising approach for tissue engineering of bone and cartilage. Actions of BMPs were regulated by various molecules and signaling pathways both in extracellular matrices and intracellular signal transduction. Wnt signaling is one of such pathways which regulates the cell fate in chondrogenesis and osteogenesis [2]. So far, three distinct intracellular cascades are known: canonical Wnt/ $\beta$-catenin pathway, JNK pathway, and Wnt/Ca2+ pathway. From observations of mutant mice, deletion of canonical Wnt $/ \beta$-catenin pathway leads to the defect of osteoblastogenesis both in endochondral and membranous ossification $[3,4]$. These studies implicated that canonical $\mathrm{Wn} / \beta$ catenin pathway prevents osteoblast from differentiation into chondrocyte and is required for osteogenesis. Interestingly, stabilized $\beta$-catenin negatively affected both osteogenesis and chondrogenesis in gain-of-function mutant study [4]. Despite these findings using mutant mice, the direct relationship between BMPs and canonical Wnt signaling is still unclear.
Gene transfer of BMP expressing plasmid drives recipient cells to produce BMP continuously [5]. High density micromass culture after transfection of BMP4 expressing plasmid differentiates mesenchymal C3H10T1/2 cells to chondrogenic lineage [6]. In the current study, lithium chloride $(\mathrm{LiCl})$ was added on the micromass culture of BMP4 gene transfected C3H10T1/2 cells to examine the effects of Wnt $/ \beta$-catenin signaling on the BMP4 mediated chondrogenic differentiation. $\mathrm{LiCl}$ inhibits glycogen synthase kinase- $3 \beta$ (GSK-3 $\beta$ ) and leads to accumulation of $\beta$-catenin. Therefore, $\mathrm{LiCl}$ is known to mimic the activity of Wnt/ $\beta$-catenin signaling [7].

From our findings in this study, we focused on cathepsin $\mathrm{H}$. Cathepsin H is a member of cathepsins, which are proteases ubiquitously expressed in animal tissues. Cathepsin family includes the serine proteases cathepsins A and G, the aspartic proteases cathepsins $\mathrm{D}$ and $\mathrm{E}$, and the lysosomal cysteine cathepsins $\mathrm{B}, \mathrm{C}, \mathrm{F}, \mathrm{H}, \mathrm{K}, \mathrm{L}, \mathrm{O}, \mathrm{S}, \mathrm{V}, \mathrm{X}$, and $\mathrm{W}[8]$. Cathepsins have numerous functions in normal and pathological processes. It is widely known that cathepsin $\mathrm{K}$ is highly expressed in osteoclasts and plays an essential role in bone resorption [9]. Cathepsins including cathepsin $\mathrm{H}$ are found activated in colorectal [10], pancreatic [11], and prostate cancer [12], glioma [13], and melanoma [14]. So, 
cathepsins could be a therapeutic target in such malignant tumors. Cathepsin $\mathrm{H}$ is known to be expressed in the adult lung and process pulmonary surfactant protein [15]. From the investigation of the development of lung, Lü et al. [16] reported that cathepsin $\mathrm{H}$ was involved in the degradation of BMP4. We hypothesized that cathepsin $\mathrm{H}$ and degradation of BMP4 are related also in $\mathrm{C} 3 \mathrm{H} 10 \mathrm{~T} 1 / 2$ cells. In the current study, we examined the gene expression and gene-silencing effects of cathepsin $\mathrm{H}$.

\section{Materials and Methods}

2.1. Plasmid Construction and Small Interfering RNA. A 1.6 $\mathrm{kb}$ mouse BMP-4 cDNA is a gift from Hogan et al. [17]. It was inserted into blunted EcoRI site of the pCAGGS expression vector which was kindly provided by Miyazaki [18]. A green fluorescent protein expressing plasmid pCAGGS-EGFP was also constructed. TOPFLASH reporter plasmid containing three copies of the TCF/LEF-1-binding site and FOPFLASH containing three copies of the mutated TCF/LEF-binding site were purchased from Upstate Biotechnology (Lake Placid, NY). A sea pansy luciferase expressing plasmid with SV40, pRL-SV40, was purchased from TOYO ink. The siRNAs for cathepsin H (siCTSH: Stealth Select RNAi) and negative control siRNA (siControl: 743519) were purchased from Invitrogen. The most effective siCTSH was selected from three candidates in our preliminary experiments.

2.2. Cell Culture. C3H10T1/2 clone 8 cells were obtained from RIKEN cell bank (Tsukuba, Japan) and maintained in Dulbecco's modified Eagle's medium (DMEM: Invitrogen, Carlsbad, CA) supplemented with $10 \%$ fatal bovine serum (Invitrogen), $50 \mathrm{U} / \mathrm{mL}$ penicillin, and $50 \mathrm{mg} / \mathrm{mL}$ streptomycin (Penstrep: Invitrogen), that is, growth medium. The micromass culture technique was modified from Ahrens et al. [19]. Trypsinized cells were resuspended in growth medium at a concentration of $10^{7}$ cells/mL. A $10 \mu \mathrm{L}$ drop of this cell suspension was placed in the center of a well in 12-well tissue culture dish (Greiner Bio-one, Kremsmuenster, Austria). The cells were allowed to adhere for $60 \mathrm{~min}$ and, then, the wells were filled with $1 \mathrm{~mL}$ of DMEM/F12 (1:1) supplemented with $1 \%$ fetal bovine serum (Invitrogen), 0.2\% BSA (Sigma, St. Louis, MO), $50 \mu \mathrm{g} / \mathrm{mL}$ ascorbic acid 2 phosphate (Sigma), Penstrep, and ITS+ (BD bioscience, Franklin Lakes, NJ), that is, differentiation medium. This medium was changed every 3 days.

2.3. In Vitro Electroporation. Before electroporation, cells were lifted with $0.25 \%$ Trypsin EDTA (Invitrogen) and dissolved in electroporation buffer [20] (75\% cytosalts; $120 \mathrm{mM}$ $\mathrm{KCl}, 0.15 \mathrm{mM} \mathrm{CaCl}_{2}, 10 \mathrm{mM} \mathrm{K}_{2} \mathrm{HPO}_{4}$ pH7.6, $5 \mathrm{mM} \mathrm{MgCl}_{2}$; $25 \%$ Opti-MEM1) at a concentration of $2.5 \times 10^{6}$ cells $/ \mathrm{mL}$. Plasmid solution was added into $600 \mu \mathrm{L}$ of cell suspension $\left(1.5 \times 10^{6}\right.$ cells $)$. Electric pulses were generated by CUY-21 in vitro (BEX, Tokyo, Japan) and applied through $4 \mathrm{~mm}$ gap cuvette. Pulse settings were $480 \mathrm{~V}, 2.5 \mathrm{~ms}, 2$ pulses at the interval of 1 second. After electroporation, the cells were recovered in growth medium overnight. On the next day of electroporation, dead cells were removed by washing with phosphate buffered saline (PBS: Invitrogen) and micromass culture was started as mentioned above. The timeline of experiments was counted from the start of micromass culture in this study.

2.4. Alcian Blue Staining and Immunostaining of Micromass. Cultured micromass was fixed with $10 \%$ formaldehyde containing $0.1 \%$ cetylpyridinium chloride and stained by $1 \%$ Alcian blue ( $\mathrm{pH} 1.0)$. For quantification, alcian blue stain was solubilized in $4 \mathrm{M}$ guanidine $\mathrm{HCl}, 50 \mathrm{mM}$ Tris $\mathrm{HCl}$ (pH7.4), 0.1\% CHAPS, and its absorbance was measured by a spectrophotometer at a wavelength of $595 \mathrm{~nm}$. For immunostaining, micromass was fixed in $-20^{\circ} \mathrm{C}$ cold ethanol. Primary antibody for BMP4 (1:100, sc-12721, Santa Cruz Biotechnology, Santa Cruz, CA) was added and incubated overnight at $4^{\circ} \mathrm{C}$. Anti-mouse IgG conjugated with Alexa Fluoro 555 was used as secondary antibody $(1: 500)$. Fluorescent signal was checked by fluorescent microscope (Olympus, Tokyo, Japan).

\subsection{Quantitative Reverse Transcription Polymerase Chain} Reaction. For quantitative reverse transcription polymerase chain reaction (qRT-PCR), total RNA was isolated using RNeasy Mini kit and RNase-free DNase set (QIAGEN, West Sussex, UK) according to the manufacturer's protocol. Oncolumn DNA digestion was routinely done. Single stranded cDNA was synthesized using High-Capacity cDNA Archive Kit (Applied Biosystems, Foster City, CA). qRT-PCR analyses were carried out with StepOnePlus and Power SYBR green master mix (Applied Biosystems). The fractional cycle number at which the fluorescence passes the threshold $(\mathrm{Ct}$ values) was used for quantification by using a comparative $\mathrm{Ct}$ method. Values of gene-of-interest (GOI) were normalized to the threshold value for GAPDH: $\Delta \mathrm{Ct}=\mathrm{Ct}(\mathrm{GOI})-\mathrm{Ct}$ (GAPDH). The Ct value of control was used as a reference. $\Delta \Delta \mathrm{Ct}=\Delta \mathrm{Ct}$ (experiment) $-\Delta \mathrm{Ct}$ (control). The fold change in mRNA expression was calculated by the following formula: $2^{-\Delta \Delta C t}$. Primers for RT-PCR were listed on Table 1.

2.6. Western Blotting. Culture medium was subjected to SDSPAGE with $10 \%$ acrylamide gel. Samples were blotted to a polyvinylidene difluoride membrane (Bio-Rad, Hercules, CA). The membranes were blocked with $2 \%$ nonfat dry milk for 1 hour at room temperature and incubated with anti-BMP4 primary antibody (1:400 Santa Cruz) at $4^{\circ} \mathrm{C}$ overnight. Then HRP-conjugated secondary anti-mouse IgG (1:1000; Santa Cruz) was applied for 2 hours at room temperature. Signals were visualized by chemiluminescence using ECL plus western blotting detection reagents (GE Healthcare, UK) with a digital luminescent image analyzer LAS-1000 (Fujifilm, Tokyo, Japan). Band intensities were analyzed by Image $1.37 \mathrm{v}$ software program (National Institutes of Health, $\mathrm{MD)}$.

2.7. Statistics. Data were presented as means \pm standard deviation of independent experiments. One-way analysis of variance (ANOVA) was performed using GraphPad Prism version 5.0 program (Graphpad software, San Diego, CA). Statistical analyses of differences between experimental groups and control were performed using Dunnett's post hoc 
TABLE 1: Primers for RT-PCR.

\begin{tabular}{lccc}
\hline Gene & Accession number & Forward $\left(5^{\prime}-3^{\prime}\right)$ & Reverse $\left(5^{\prime}-3^{\prime}\right)$ \\
\hline BMP4 & NM_007554.1 & gaggagtttccatcacgaaga & gctctgccgaggagatca \\
Sox9 & NM_011448.2 & cagcaagactctgggcaag & tccacgaagggtctcttctc \\
aggrecan & NM_007424.1 & ccagcctacaccccagtg & gagggtgggaagccatgt \\
Col2a1 & NM_031163.2 & agtaccggagctcgaggag & gatcacccttggcaccag \\
Noggin & NM_008711 & cggccagcactatctacaca & gttcgatgaggtccaccaag \\
Gremlin 1 & NM_011824 & gaggacccacggaagtga & cctcagctgttggcagtagg \\
Follistatin & NM_008046 & tggattagcctatgagggaaag & tggaatcccataggcatttt \\
Cathepsin H & NM_007801.1 & gaggaagattcaagcccaca & aaaactggttcaacgccatt \\
\hline
\end{tabular}

test. Student's $t$-test was used for the analysis in the genesilencing experiment.

\section{Results}

3.1. Electroporatic Transfer of BMP4 Expressing Plasmid Induced Chondrogenesis. To confirm the chondrogenesis, pCAGGS-BMP4 transfected C3H10T1/2 cells were cultured in micromass. From day 3, the cells metamorphosed into round shape. Alcian blue staining at day 6 exhibited positive stain. The intensity of Alcian blue staining showed dosedependent increase depending on the amount of plasmid used at electroporation (Figure 1(a)). Gene expression profiles were analyzed by qRT-PCR at day 3. BMP4 mRNA expression increased in the dose-dependent manner of the plasmid amount. Sox 9 mRNA expression was not affected by the dose of plasmid. Aggrecan and Col2al mRNA showed marked dose-dependent increase (Figure 1(b)).

3.2. The Effect of LiCl Treatment on Gene Transfected Cells. $\mathrm{LiCl}$ was added to the micromass culture of pCAGGS-BMP4 transfected $\mathrm{C} 3 \mathrm{H} 10 \mathrm{~T} 1 / 2$ cells. To correct the osmolality of medium, $\mathrm{NaCl}$ was added up to $25 \mathrm{mM}$ together with $\mathrm{LiCl}$ $(\mathrm{NaCl} ; \mathrm{LiCl}=25 ; 0,20 ; 5,15 ; 10,25 ; 0 \mathrm{mM})$. Alcian blue staining of micromass at day 6 was inhibited by the addition of $\mathrm{LiCl}$ in dose-dependent manner. The supplementation of wnt3a protein also inhibited Alcian blue staining of micromass at the concentration of $50 \mathrm{mM}$ significantly (Figures 2(a) and 2(b)). To test the effect of $\mathrm{LiCl}$ on the expression levels of other plasmid, pCAGGS-EGFP or pRL-SV40 was transfected into $\mathrm{C} 3 \mathrm{H} 10 \mathrm{~T} 1 / 2$ cells, and cells were cultured in micromass under the same concentrations of $\mathrm{LiCl}$. The expression of EGFP was similar to that of the control in 5 and $10 \mathrm{mM}$ of $\mathrm{LiCl}$ treatment and higher in the $25 \mathrm{mM} \mathrm{LiCl}$ treatment (Figure 2(c)). The luciferase assay showed similar tendencies to the EGFP expression (Figure 2(d)).

3.3. LiCl Treatment Activated $\beta$-Catenin/TCF Pathway. To confirm the activation of canonical Wnt signaling in the $\mathrm{LiCl}$ treated micromass, TOPFLASH or FOPFLASH $(20 \mu \mathrm{g} /$ cuvette), pRL-SV40 (20 $\mu \mathrm{g})$ and pCAGGS-BMP4 (20 $\mu \mathrm{g})$, was cotransfected by electroporation. After a 3-day culture in micromass with or without $\mathrm{LiCl}$, luciferase activity of cell lysate was assessed. The promoter activity of TOPFLASH was enhanced by addition of LiCl (Figure 2(e)).
3.4. LiCl Treatment Suppressed Chondrogenic Differentiation of $\mathrm{C} 3 \mathrm{H} 10 \mathrm{T1} / 2$. The gene expression profiles of $\mathrm{C} 3 \mathrm{H} 10 \mathrm{~T} 1 / 2$ cells transfected with pCAGGS-BMP4 (30 $\mathrm{g} /$ cuvette) were analyzed at day 3 (Figure 3(a)). The levels of BMP4 mRNA did not show significant difference by $\mathrm{LiCl}$ treatment. Sox 9 mRNA expression was significantly suppressed at $25 \mathrm{mM}$ $\mathrm{LiCl}$ treatment. Aggrecan and Col2al gene were dosedependently inhibited by $\mathrm{LiCl}$. The expression levels of antagonists against BMPs were also investigated. Noggin mRNA was dose-dependently suppressed. Gremlin 1 expression were not affected by $\mathrm{LiCl}$. The levels of follistatin were increased in dose-dependent manner. The expression levels of cathepsin $\mathrm{H}$ was increased in a dose-dependent manner of $\mathrm{LiCl}$.

3.5. LiCl Treatment Remarkably Suppressed BMP4 Protein Accumulation. The conditioned medium used in the micromass culture of BMP4 transfected cells was subjected to western blot analysis (Figure 3(b)). $\mathrm{LiCl}$ treatment dose dependently reduced the accumulation of BMP4 protein in the culture medium. Localization of BMP4 protein was assessed by immunocytochemical staining of micromass (Figure 3(c)). BMP4 protein in the cells and extracellular matrix was also reduced by $\mathrm{LiCl}$ treatment in dose dependent manner.

3.6. Gene Silencing of Cathepsin H Stimulated the Protein Expression of BMP4. RNA interference for cathepsin $\mathrm{H}$ was carried out by electroporatic transfer of small interfering RNA molecule. After cotransfection of siCTSH or siControl (300 pmol/cuvette) with pCAGGS-BMP4 (30 $\mu \mathrm{g} /$ cuvette) by electroporation, cells were cultured in micromass. qRTPCR at day 3 showed suppression of cathepsin H mRNA expression. Cathepsin $\mathrm{H}$ gene silencing slightly increased the expression level of BMP4 by $1.5 \pm 0.4$-folds (Figure 4(a)). Western blotting for BMP4 showed that cathepsin $\mathrm{H}$ gene silencing remarkably increased BMP4 protein expression by $2.9 \pm 1.4$-folds (Figure 4(b)). Alcian blue staining of micromass at day 6 showed significant increase in siCTSH transfected cells (Figure 3(c)).

\section{Discussion}

In the current study, BMP4 expressing cells were treated with $\mathrm{LiCl}$ which stabilize $\beta$-catenin and activate $\mathrm{Wnt} / \beta$-catenin signaling. $\mathrm{LiCl}$ treatment did not affect the mRNA expression 


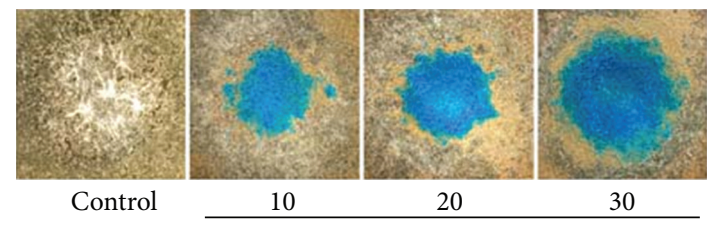

pCAGGS-BMP4

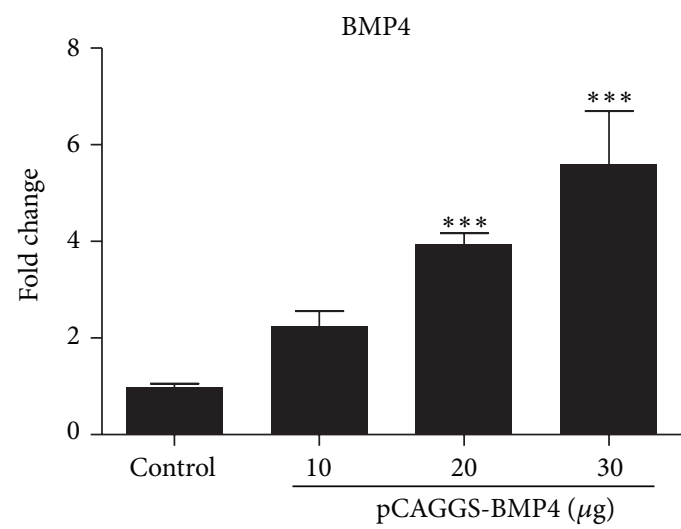

Aggrecan

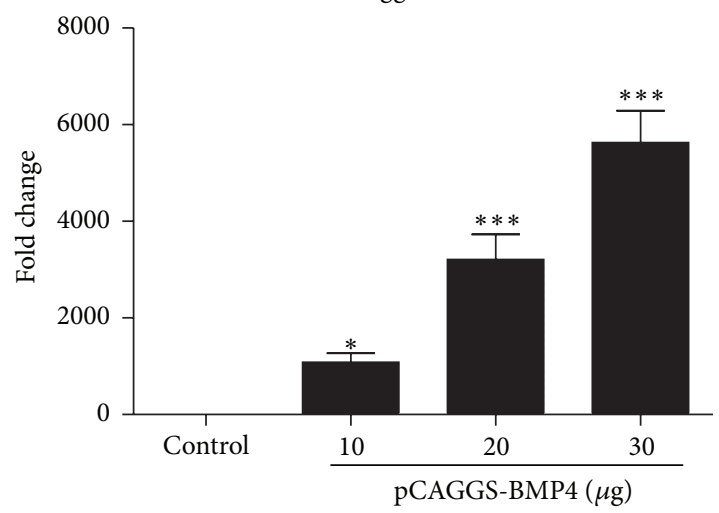

(a)
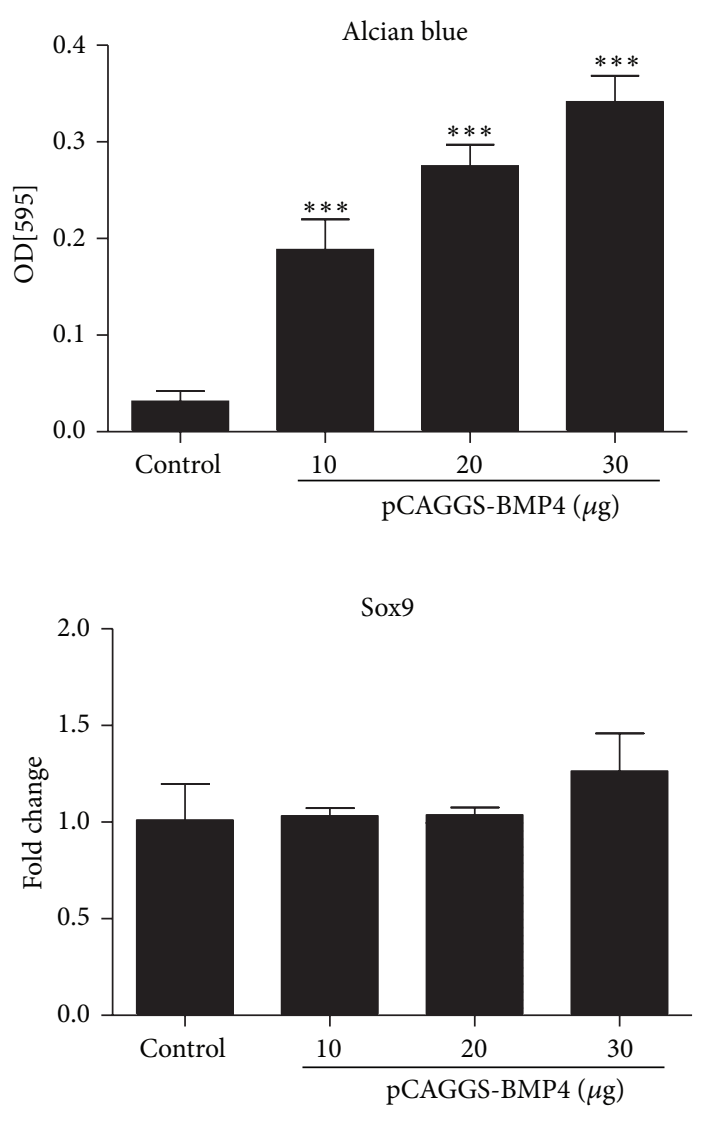

Col2a1

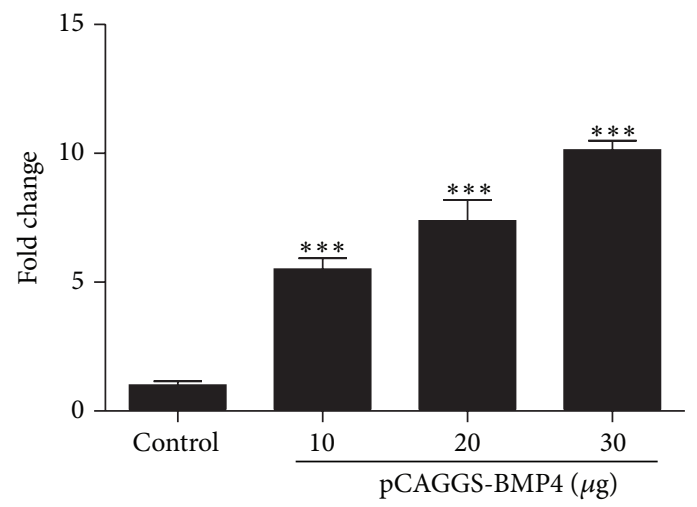

(b)

FIGURE 1: (a) Alcian blue staining of cultured micromass and quantification. C3H10T1/2 cells were transfected with BMP4 expressing plasmid, pCAGGS-BMP4. Cultured micromass was stained at day 6. The indicated amount of plasmid was supplemented in a $4 \mathrm{~mm}$ cuvette (600 $\mu \mathrm{L}$ ) at the electroporation. (b) Quantitative RT-PCR for BMP4, Sox9, Aggrecan, and Col2al mRNA at day 3. BMP4 mRNA expression levels and chondrogenic properties were increased in the dose dependent manner of pCAGGS-BMP4. ${ }^{*} P<0.05,{ }^{* * *} P<0.001$.

from transfected BMP4 expressing plasmid. However, $\mathrm{LiCl}$ dramatically reduced the accumulation of BMP 4 protein both in conditioned medium and micromass. This discrepancy between gene expression and protein accumulation could be attributed to the degradation of BMP4 protein. Cathepsin $\mathrm{H}$ which is known to be involved in the degradation of BMP4 protein in the developmental stage of lung [16] showed increase in the dose-dependent manner of LiCl. Gene silencing of cathepsin $\mathrm{H}$ enhanced the protein accumulation of
BMP4 from expressing plasmid. These results confirmed that cathepsin $\mathrm{H}$ is involved in the degradation of BMP4 protein in the $\mathrm{C} 3 \mathrm{H} 10 \mathrm{~T} 1 / 2$ and its expression was regulated by Wnt $\beta$ catenin signaling. The current study suggested that $\mathrm{LiCl}$ treatment which mimics $\mathrm{Wnt} / \beta$-catenin signaling controls the biological activity of BMP4 through the degradation process by cathepsin $\mathrm{H}$, for the first time.

Cathepsin $\mathrm{H}$ is a protease which has both endopeptidase and aminopeptidase activities [21]. From the spatiotemporal 


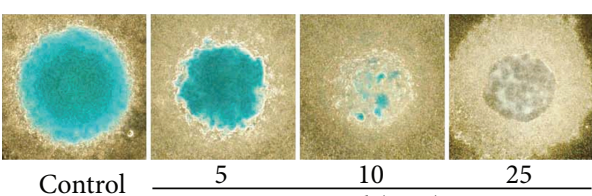

Control

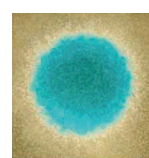

Control $\mathrm{LiCl}(\mathrm{mM})$

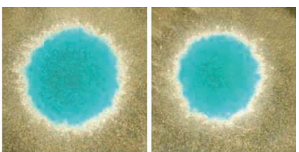

10

(a)

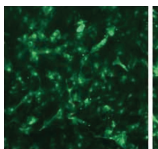

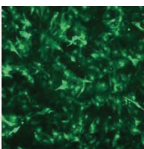

Control

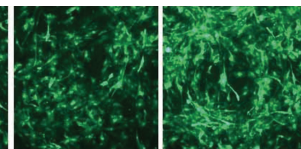

$\mathrm{LiCl}(\mathrm{mM})$

pCAGGS-EGFP $(30 \mu \mathrm{g})$

(c)

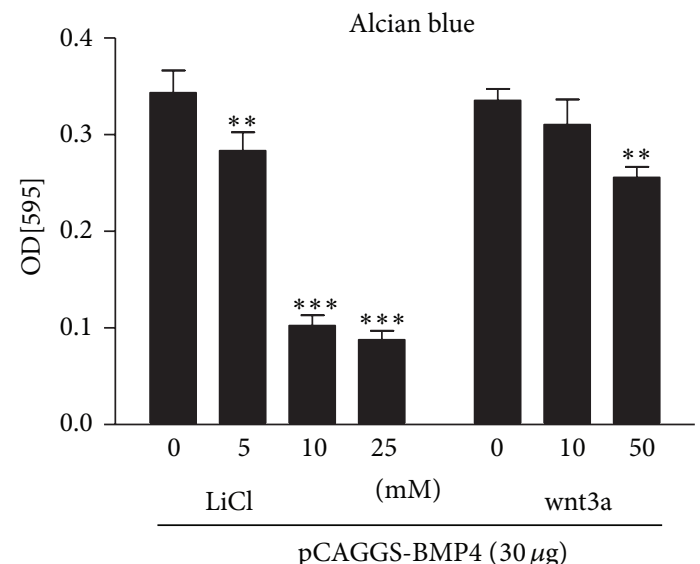

(b)

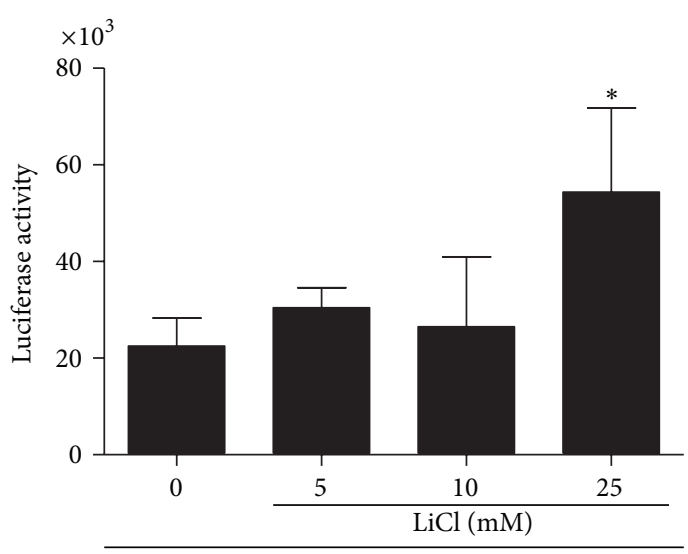

pRL-SV40 $(30 \mu \mathrm{g})$

(d)

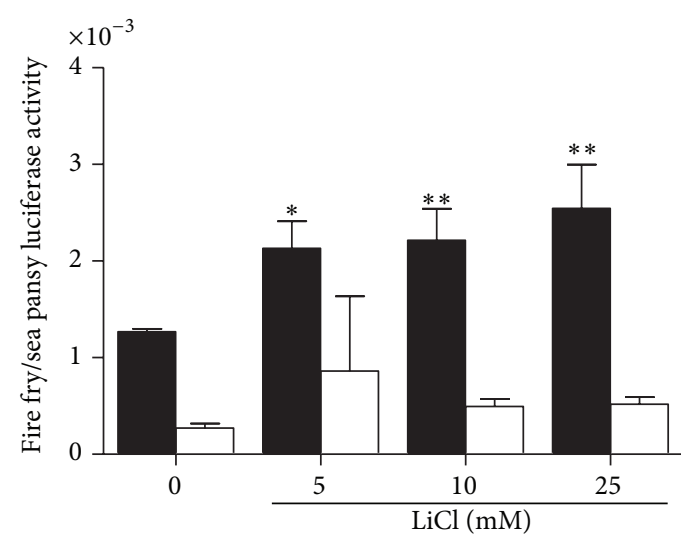

(e)

FIGURE 2: (a) Alcian blue staining of micromass. pCAGGS-BMP4 transfected C3H10T1/2 was cultured in micromass for 6 days with $\mathrm{LiCl}$ or wnt3a supplementation. (b) Quantitative analysis of Alcian blue staining. LiCl treatment and wnt3a supplementation suppressed chondrogenic differentiation. (c) EGFP expression of pCAGGS-EGFP (30 $\mu \mathrm{g} /$ cuvette) transfected cells at day 3 . LiCl did not alter EGFP expression in 5 and $10 \mathrm{mM}$ and stimulated EGFP in $25 \mathrm{mM}$. (d) Sea pansy luciferase expressing gene, pRL-SV40 (30 $\mu \mathrm{g} / \mathrm{cuvette),} \mathrm{was}$ transfected. Luciferase activity was measured at day 3 . Luciferase activity was not changed in 5 and $10 \mathrm{mM}$ of LiCl treatment and was higher in 25 mM. (e) Cells were cotransfected with TOPFLASH (open bar) or FOPFLASH (solid bar) (20 $\mu \mathrm{g} /$ cuvette), pRL-SV40 (20 $\mu \mathrm{g}$ ) and pCAGGSBMP4 $(20 \mu \mathrm{g})$. Luciferase activity in cell lysates was measured at day 3 . The data was normalized to the activity of cotransfected Renilla control. $\mathrm{LiCl}$ treatment dose dependently increased $\beta$-catenin in the cells. ${ }^{*} P<0.05,{ }^{* *} P<0.01$, and ${ }^{* * *} P<0.001$. 

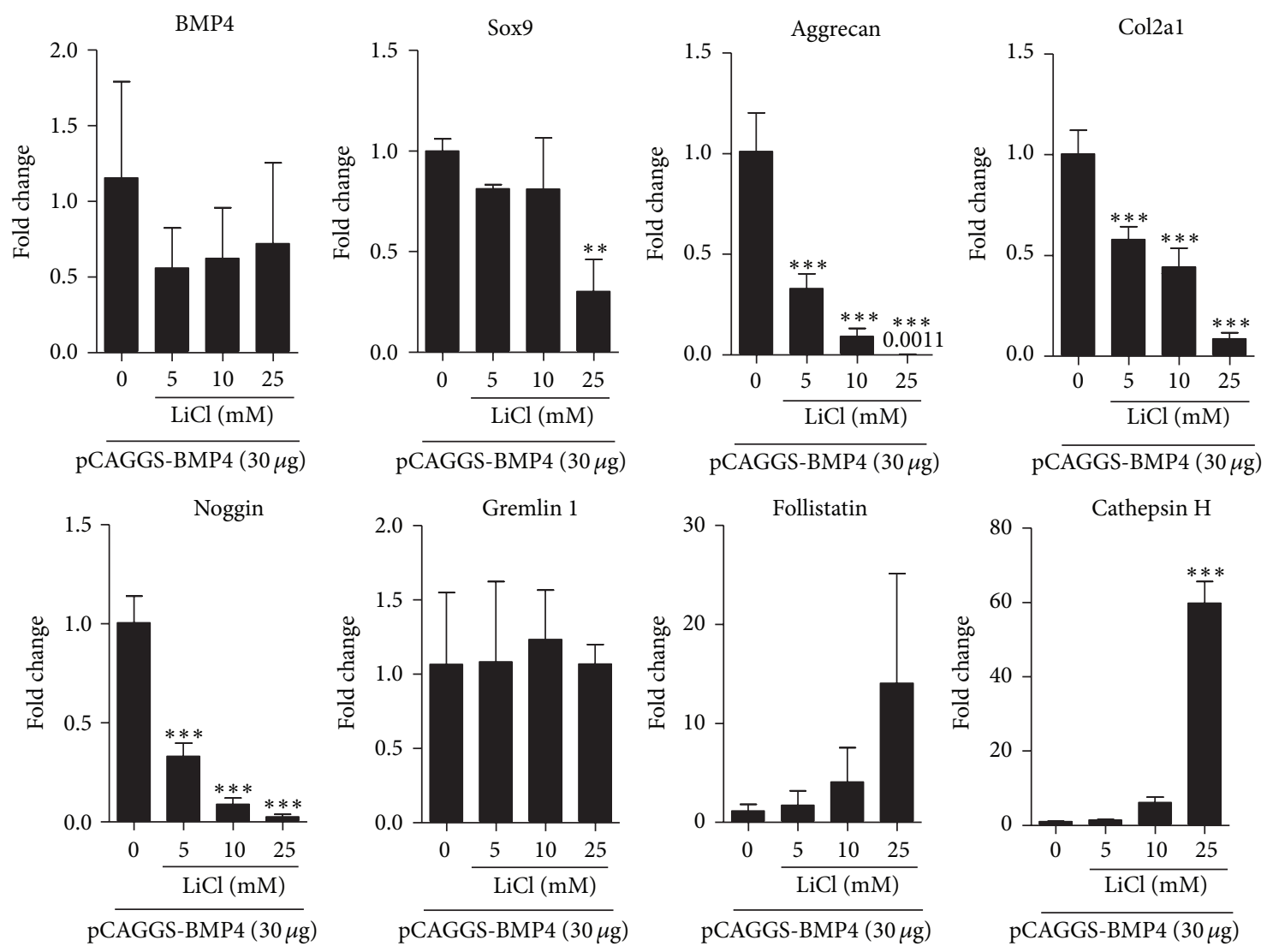

(a)

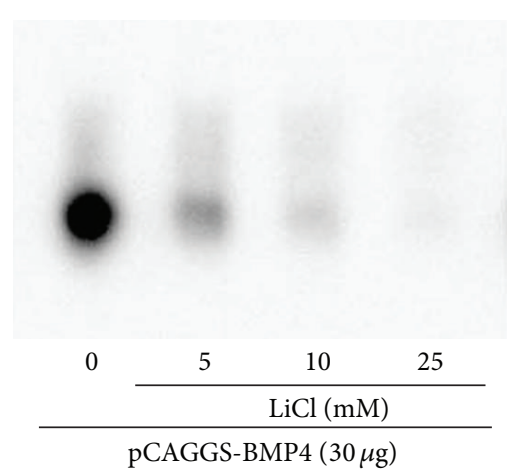

(b)

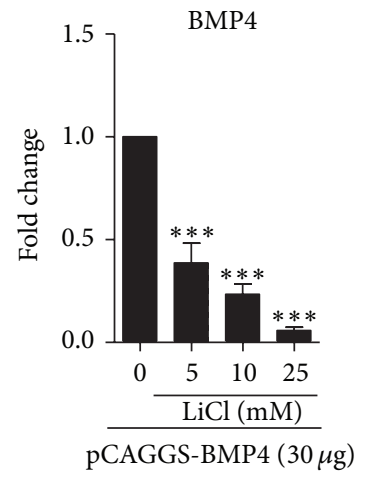

pCAGGS-BMP4 $(30 \mu \mathrm{g})$

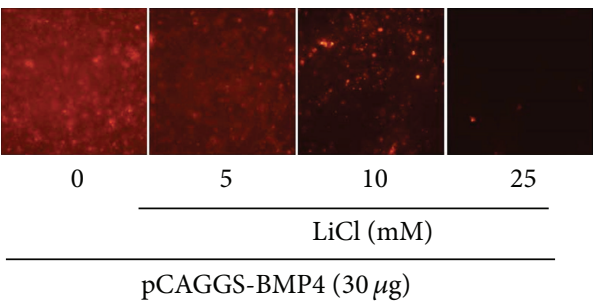

(c)

FIGURE 3: (a) Gene expression profiles of pCAGGS-BMP4 transfected cells cultured in micromass at day 3. (b) Western blot analysis of culture medium for BMP4 at day 3. (c) Immunostaining of micromass for BMP4 at day 3. BMP4 gene expression levels were not significantly altered by $\mathrm{LiCl}$. However, BMP4 protein accumulation in both culture medium and cells was dose dependently decreased by LiCl. Aggrecan and Col2al mRNA expression was decreased by LiCl. BMP antagonist, noggin, gremlin 1 and follistatin showed different responses to LiCl. The mRNA expression of cathepsin $\mathrm{H}$ was up-regulated by $\mathrm{LiCl} .{ }^{* *} \mathrm{P}<0.01,{ }^{* * *} \mathrm{P}<0.001$.

expression pattern in the developing lung, Lü et al. [16] identified the degradation of BMP4 by cathepsin $\mathrm{H}$ as a posttranslational system which controls the bioavailability of BMP4. Pharmacological inhibitors of cathepsin $\mathrm{H}$ increased BMP4 accumulation and disrupted the lung morphogenesis. In the current study, our result of BMP4 protein and siRNA analyses ensured that degradation of BMP4 by cathepsin $\mathrm{H}$ occurs in other situations than lung development. From our observation by immunostaining and western blotting for
BMP4, BMP4 protein was diminished by $\mathrm{LiCl}$ not only in conditioned medium but also in the cells. These results suggest that degradation of BMP4 occurred in the lysosomes or endosomes of the cells. However, it could not be denied that cathepsin $\mathrm{H}$ degrades BMP4 extracellularly. Our preliminary experiment (data not shown) and Lü's data [16] failed to demonstrate BMP degradation by simple in vitro mixture of BMP4 and cathepsin H proteins. This may imply that cathep$\sin \mathrm{H}$ requires another cofactor or specific environment to 

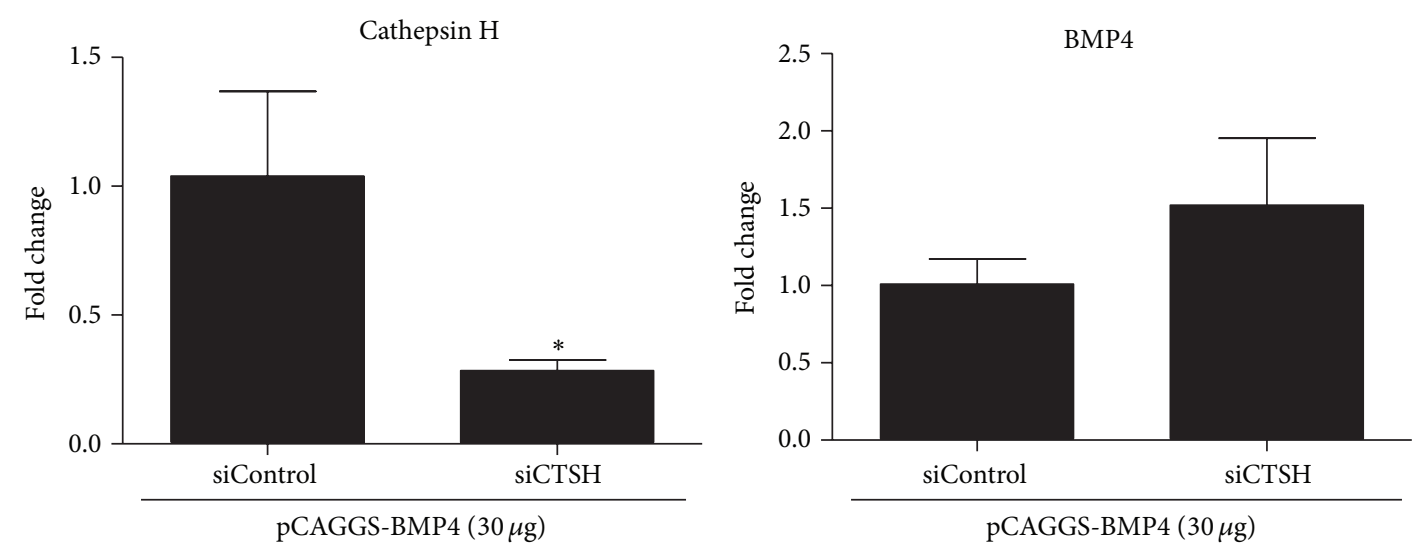

(a)
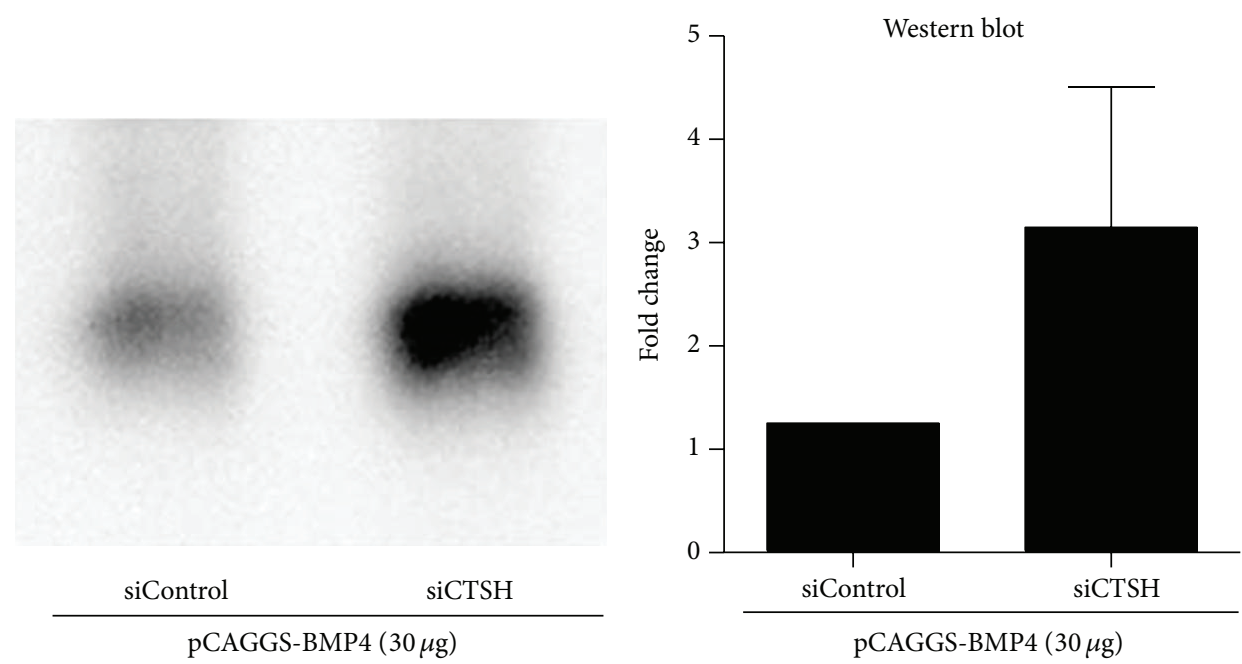

(b)
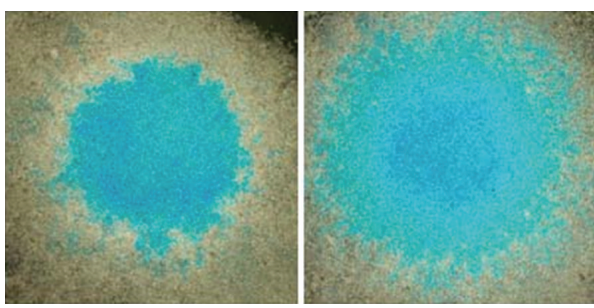

siControl siCTSH
pCAGGS-BMP4 $(30 \mu \mathrm{g})$

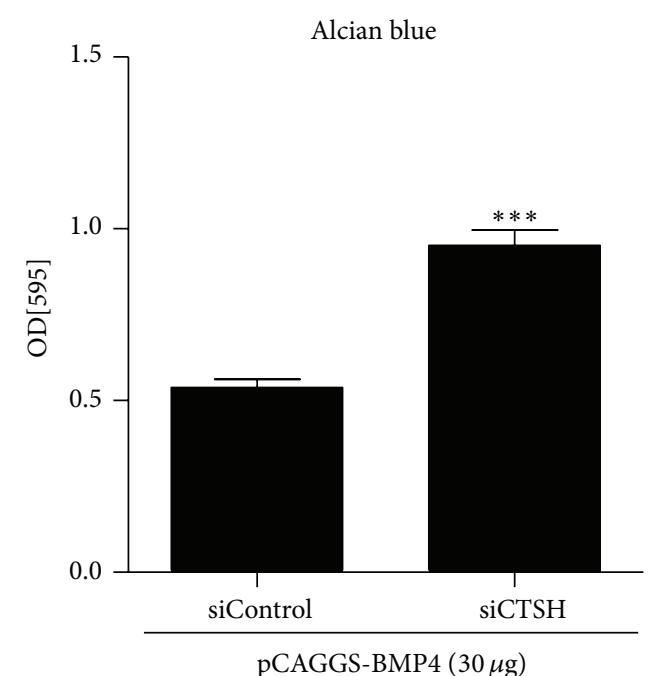

(c)

FIGURE 4: Gene silencing of cathepsin H was carried out by electroporatic gene transfer of small interfering RNA. siCTSH targeting cathepsin $\mathrm{H}$ or siControl (300 pmol/cuvette each) was transfected with pCAGGS-BMP4 (30 $\mu \mathrm{g} /$ cuvette). (a) Quantitative RT-PCR at day 3. Cathepsin $\mathrm{H}$ mRNA expression was inhibited significantly. (b) Western blot analysis for BMP4 in the culture medium at day 3 showed marked increase of BMP4. (c) Alcian blue staining of micromass showed significant increase by gene silencing of cathepsin $\mathrm{H} .{ }^{*} P<0.05,{ }^{* * *} P<0.001$. 
exhibit BMP4 degradation activity. Lysosomal cathepsins require slightly acidic environment, such as that found in the lysosomes [8]. So, it is likely that cathepsin H degrades BMP4 in the lysosomes or endosomes. Ishihara et al. [22] analyzed global gene expression using microarray at the fracture site adenovirally infected by BMP genes in an equine model. The expression of cathepsin $\mathrm{H}$ was greater in BMP-2 and - 6 treated fracture callus than that control. This may imply cathepsin $\mathrm{H}$ plays a certain role in the activity of BMPs at fracture site. Only a few researches have shed light on the degradation of BMPs. There are many issues awaiting investigation, such as degradation of other members of TGF- $\beta$ superfamily, BMP degradation ability of other members of cathepsin family, and the details of degradation process.

BMP4 protein is synthesized as an inactive precursor and undergoes proteolytic cleavage by subtilisin-like proprotein convertase at the specific site to be activated [23, 24]. So far, no evidence has been shown that cathepsins are involved in the cleavage of BMP precursors. According to suppliers information, the antibody for BMP4 used in the current study reacts with both $\mathrm{BMP} 4$ precursor and mature BMP4. In our immunocytostaining for $\mathrm{BMP} 4, \mathrm{LiCl}$ treatment also suppressed the BMP4 accumulation in the cells. Cathepsin $\mathrm{H}$ is a lysosomal cysteine protease. Therefore, cathepsin $\mathrm{H}$ seemed to degrade both BMP4 precursors and mature BMP4 in cytoplasm before its extracellular secretion.

Noggin is a well-known antagonist of BMPs. Noggin binds to BMPs with high affinity and blocks interaction between BMPs and their receptors [25]. BMPs including BMP-4 induce the expression of noggin [26]. This phenomenon suggests that there exists a negative feedback loop to limit the activities of BMPs. The suppression of noggin expression along with the reduction of BMP4 accumulation in our observation is consistent with previous findings. Gremlin expression was not influenced by $\mathrm{LiCl}$ in our data. Sun et al. suggested that gremlin is also expressed in developing lung with BMP4 [27]. Interestingly, gremlin interacts with BMP4 precursor intracellularly and efficiently inhibits the activity of BMP4. Cathepsin $\mathrm{H}$ is also expressed in developing lung and inhibits BMP4. There may exist an interplay between gremlin and cathepsin $\mathrm{H}$. Follistatin also binds BMP4 and inhibits its activity extracellularly. On the contrary to noggin, it is known that follistatin expression is downregulated by BMP4 in chondrocytes [28]. The decrease of BMP4 accumulation by $\mathrm{LiCl}$ seemed to stimulate the expression of follistatin by the reduction of inhibition in our experiments.

In the current study, $\mathrm{LiCl}$ was used to mimic the action of canonical Wnt/ $\beta$-catenin signaling. The presence of $\mathrm{LiCl}$ inhibits glycogen synthase kinase- $3 \beta$ (GSK-3 $\beta$ ). Intracellular $\beta$-catenin undergoes digestion via ubiquitin proteasome system when the receptor frizzled and coreceptor LRP were not bound with Wnt ligand. The inhibition of GSK$3 \beta$ blocks this digestion and increases the accumulation of intracellular $\beta$-catenin [7]. LiCl inhibited the chondrogenic differentiation of $\mathrm{C} 3 \mathrm{H} 10 \mathrm{~T} 1 / 2$ micromass culture treated with BMP2 protein supplementation [29]. This data suggested that $\mathrm{Wnt} / \beta$-catenin signaling directly inhibits chondrogenesis. In our experiments, $\mathrm{Wnt} / \beta$-catenin signaling synergistically inhibits chondrogenesis of $\mathrm{C} 3 \mathrm{H} 10 \mathrm{~T} 1 / 2$ cells through both the degradation of BMP4 and direct inhibition by $\mathrm{Wnt} / \beta$ catenin signaling.

Gene silencing of cathepsin H in BMP4 expressing cells exhibited greater accumulation of BMP4 protein in the absence of $\mathrm{LiCl}$. This result without mimicking Wnt $/ \beta$-catenin signaling may suggest that catalytic processes through cathepsin $\mathrm{H}$ are active at a certain level in C3H10T1/2. Although this activity could vary according to types of cells and conditions, the inhibition of cathepsin $\mathrm{H}$ has a potential to enhance the effects of BMPs in the gene-based tissue engineering of bone and cartilage.

\section{Conclusion}

In conclusion, upregulation of canonical wnt/ $\beta$-catenin signaling mimicked by $\mathrm{LiCl}$ caused discrepancy between mRNA and protein expression of BMP4. Cathepsin H, a cysteine protease which degrades BMP4 mRNA expression, was also upregulated by $\mathrm{LiCl}$ treatment. Gene silencing of cathepsin $\mathrm{H}$ enhanced BMP4 accumulation from BMP4 expressing cells. $\mathrm{Wnt} / \beta$-catenin signaling may regulate the biological activity of BMP4 through the regulation of cathepsin $\mathrm{H}$.

\section{Acknowledgments}

The authors would like to thank Katsuyoshi Shoji and Michiko Fukuyama for their technical assistance.

\section{References}

[1] A. H. Reddi, "Morphogenesis and tissue engineering of bone and cartilage: inductive signals, stem cells, and biomimetic biomaterials," Tissue Engineering, vol. 6, no. 4, pp. 351-359, 2000.

[2] E. Kolpakova and B. R. Olsen, "Wnt/ $\beta$-catenin-a canonical tale of cell-fate choice in the vertebrate skeleton," Developmental Cell, vol. 8, no. 5, pp. 626-627, 2005.

[3] T. F. Day, X. Guo, L. Garrett-Beal, and Y. Yang, "Wnt/ $\beta$-catenin signaling in mesenchymal progenitors controls osteoblast and chondrocyte differentiation during vertebrate skeletogenesis," Developmental Cell, vol. 8, no. 5, pp. 739-750, 2005.

[4] T. P. Hill, D. Später, M. M. Taketo, W. Birchmeier, and C. Hartmann, "Canonical Wnt $/ \beta$-catenin signaling prevents osteoblasts from differentiating into chondrocytes," Developmental Cell, vol. 8, no. 5, pp. 727-738, 2005.

[5] K. N. Kishimoto, Y. Y. Watanabe, H. H. Nakamura, and S. S. Kokubun, "Ectopic bone formation by electroporatic transfer of bone morphogenetic protein-4 gene," Bone, vol. 31, no. 2, pp. 340-347, 2002.

[6] K. N. Kishimoto and Y. Watanabe, "Bone formation by BMP gene transfection," in Electroporation and Sonoporation in Developmental Biology, H. Nakamura, Ed., pp. 263-270, Springer, Berlin, Germany, 2009.

[7] P. S. Klein and D. A. Melton, "A molecular mechanism for the effect of lithium on development," Proceedings of the National Academy of Sciences of the United States of America, vol. 93, no. 16, pp. 8455-8459, 1996.

[8] V. Turk, V. Stoka, O. Vasiljeva et al., "Cysteine cathepsins: from structure, function and regulation to new frontiers," Biochimica et Biophysica Acta, vol. 1824, no. 1, pp. 68-88, 2012. 
[9] A. G. Costa, N. E. Cusano, B. C. Silva, S. Cremers, and J. P. Bilezikian, "Cathepsin K: its skeletal actions and role as a therapeutic target in osteoporosis," Nature Reviews Rheumatology, vol. 7, no. 8, pp. 447-456, 2011.

[10] D. Kuester, H. Lippert, A. Roessner, and S. Krueger, "The cathepsin family and their role in colorectal cancer," Pathology Research and Practice, vol. 204, no. 7, pp. 491-500, 2008.

[11] S. Sulpizio, N. Franceschini, A. Piattelli, P. di Sebastiano, P. Innocenti, and F. Selvaggi, "Cathepsins and pancreatic cancer: the 2012 update," Pancreatology, vol. 12, pp. 395-401, 2012.

[12] Z. Jevnikar, M. Rojnik, P. Jamnik, B. Doljak, U. P. Fonovic, and J. Kos, "Cathepsin $\mathrm{H}$ mediates the processing of talin and regulates migration of prostate cancer cells," Journal of Biological Chemistry, vol. 288, pp. 2201-2209, 2013.

[13] M. Sivaparvathi, R. Sawaya, Z. L. Gokaslan, S. K. Chintala, and J. S. Rao, "Expression and the role of cathepsin $\mathrm{H}$ in human glioma progression and invasion," Cancer Letters, vol. 104, no. 1, pp. 121-126, 1996.

[14] E. Frohlich, B. Schlagenhauff, M. Mohrle, E. Weber, C. Klessen, and G. Rassner, "Activity, expression, and transcription rate of the cathepsins B, D, H, and L in cutaneous malignant melanoma," Cancer, vol. 91, pp. 972-982, 2001.

[15] T. Ueno, S. Linder, C.-L. Na, W. R. Rice, J. Johansson, and T. E. Weaver, "Processing of pulmonary surfactant protein B by napsin and cathepsin H," Journal of Biological Chemistry, vol. 279, no. 16, pp. 16178-16184, 2004.

[16] J. Lü, J. Qian, D. Keppler, and W. V. Cardoso, "Cathespin H is an Fgf10 target involved in Bmp4 degradation during lung branching morphogenesis," Journal of Biological Chemistry, vol. 282, no. 30, pp. 22176-22184, 2007.

[17] C. M. Jones, K. M. Lyons, and B. L. M. Hogan, "Involvement of Bone Morphogenetic Protein-4 (BMP-4) and Vgr-1 in morphogenesis and neurogenesis in the mouse," Development, vol. 111, no. 2, pp. 531-542, 1991.

[18] J.-I. Miyazaki, S. Takaki, K. Araki et al., "Expression vector system based on the chicken $\beta$-actin promoter directs efficient production of interleukin-5," Gene, vol. 79, no. 2, pp. 269-277, 1989.

[19] P. B. Ahrens, M. Solursh, and R. S. Reiter, "Stage-related capacity for limb chondrogenesis in cell culture," Developmental Biology, vol. 60, no. 1, pp. 69-82, 1977.

[20] M. J. B. van den Hoff, F. F. M. Moorman, and W. H. Lamers, "Electroporation in 'intracellular' buffer increases cell survival," Nucleic Acids Research, vol. 20, no. 11, article 2902, 1992.

[21] V. Turk, B. Turk, and D. Turk, "Lysosomal cysteine proteases: facts and opportunities," The EMBO Journal, vol. 20, no. 17, pp. 4629-4633, 2001.

[22] A. Ishihara, K. M. Shields, A. S. Litsky et al., "Osteogenic gene regulation and relative acceleration of healing by adenoviralmediated transfer of human BMP-2 or -6 in equine osteotomy and ostectomy models," Journal of Orthopaedic Research, vol. 26, no. 6, pp. 764-771, 2008.

[23] D. B. Constam and E. J. Robertson, "Regulation of bone morphogenetic protein activity by pro domains and proprotein convertases," Journal of Cell Biology, vol. 144, no. 1, pp. 139-149, 1999.

[24] Y. Cui, F. Jean, G. Thomas, and J. L. Christian, "BMP-4 is proteolytically activated by furin and/or PC6 during vertebrate embryonic development," The EMBO Journal, vol. 17, no. 16, pp. 4735-4743, 1998.

[25] L. B. Zimmerman, J. M. de Jesús-Escobar, and R. M. Harland, "The Spemann organizer signal noggin binds and inactivates bone morphogenetic protein 4," Cell, vol. 86, no. 4, pp. 599-606, 1996.

[26] E. Gazzerro, V. Gangji, and E. Canalis, "Bone morphogenetic proteins induce the expression of noggin, which limits their activity in cultured rat osteoblasts," The Journal of Clinical Investigation, vol. 102, no. 12, pp. 2106-2114, 1998.

[27] J. Sun, F.-F. Zhuang, J. E. Mullersman et al., "BMP4 activation and secretion are negatively regulated by an intracellular Gremlin-BMP4 interaction," Journal of Biological Chemistry, vol. 281, no. 39, pp. 29349-29356, 2006.

[28] G. Tardif, D. Hum, J.-P. Pelletier, C. Boileau, P. Ranger, and J. Martel-Pelletier, "Differential gene expression and regulation of the bone morphogenetic protein antagonists follistatin and gremlin in normal and osteoarthritic human chondrocytes and synovial fibroblasts," Arthritis and Rheumatism, vol. 50, no. 8, pp. 2521-2530, 2004.

[29] L. Fischer, G. Boland, and R. S. Tuan, "Wnt signaling during BMP-2 stimulation of mesenchymal chondrogenesis," Journal of Cellular Biochemistry, vol. 84, no. 4, pp. 816-831, 2002. 


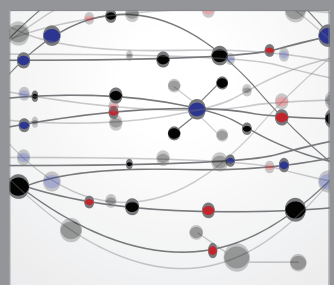

The Scientific World Journal
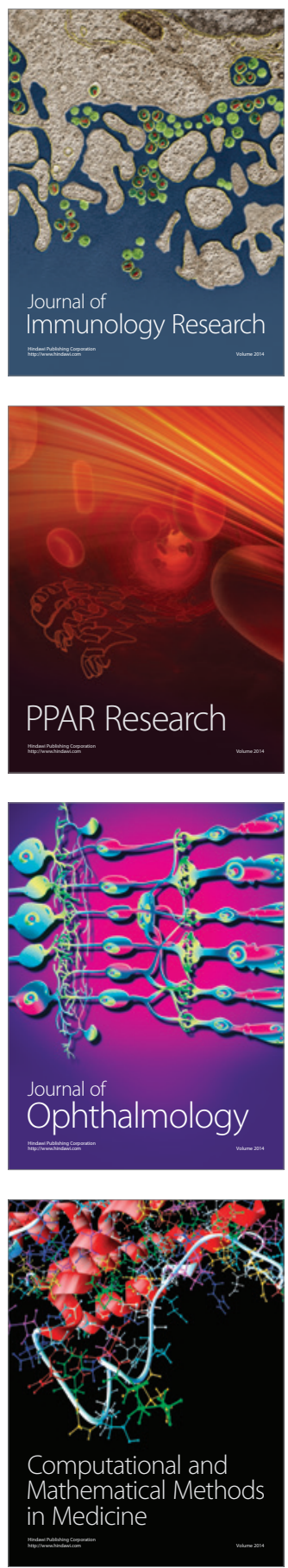

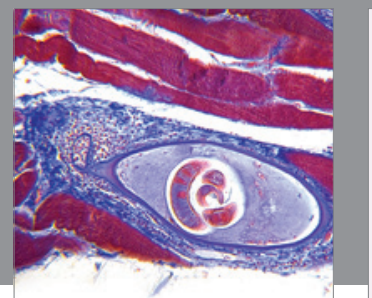

Gastroenterology

Research and Practice
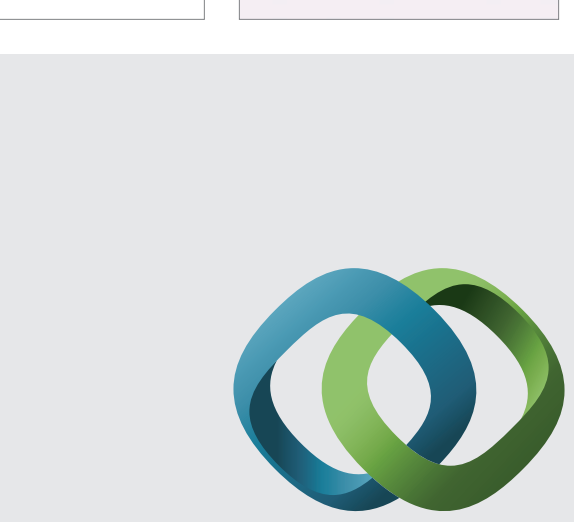

\section{Hindawi}

Submit your manuscripts at

http://www.hindawi.com
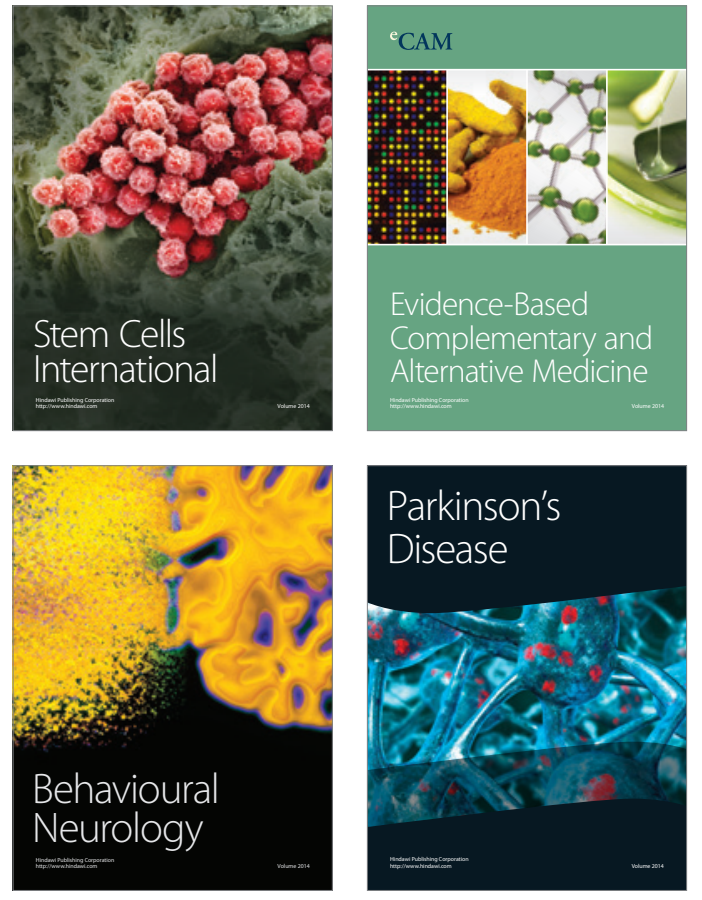
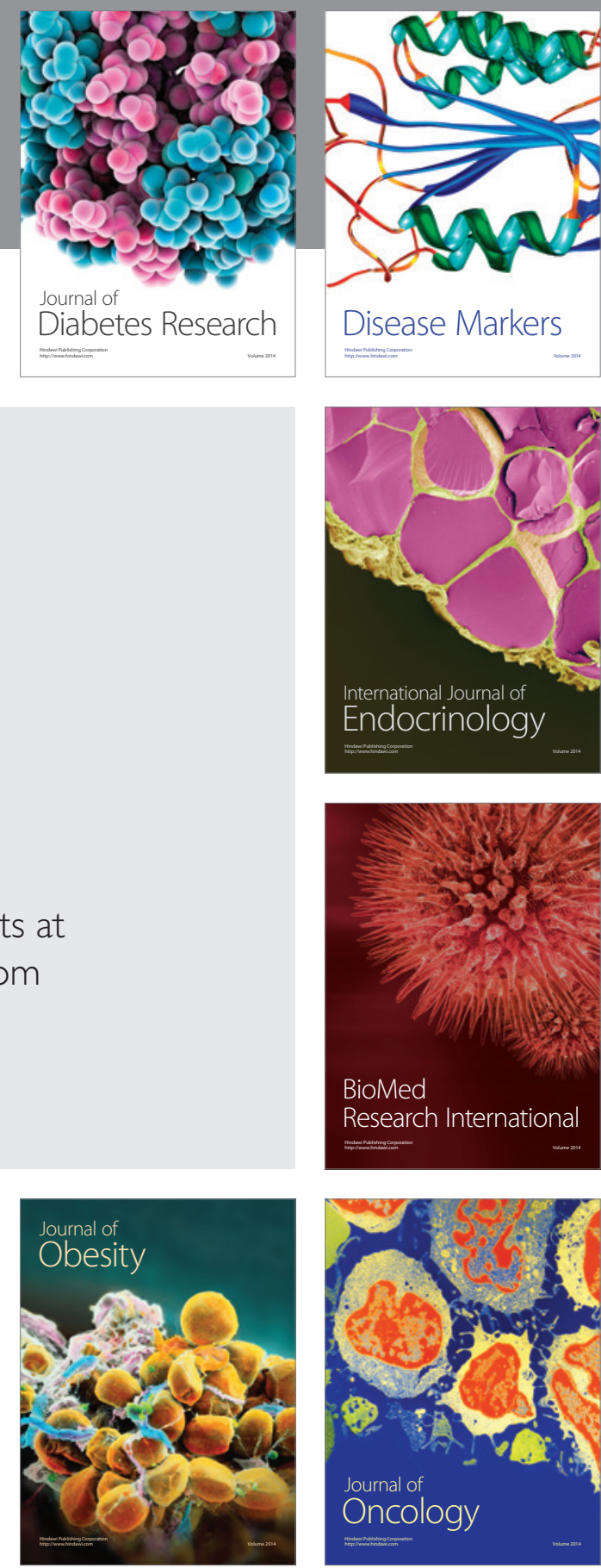

Disease Markers
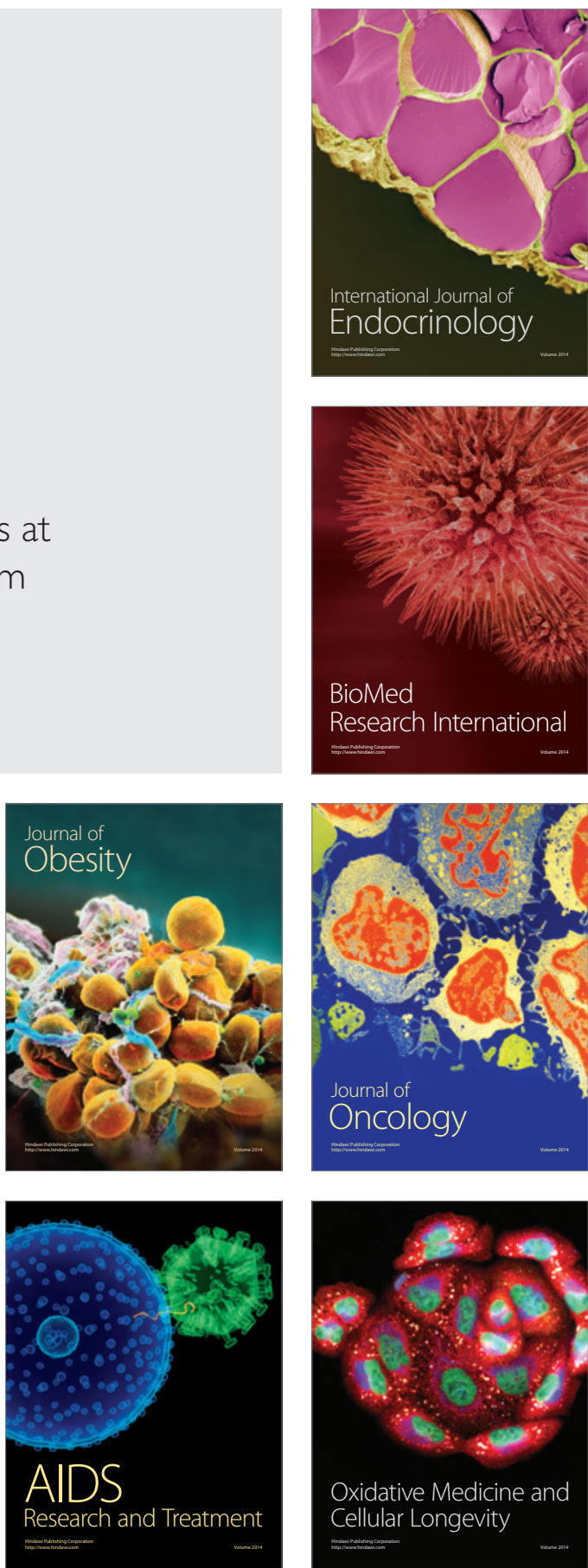